\title{
Sprawozdania
}

\section{Sprawozdanie z Międzynarodowej Konferencji Naukowej: „Unia Europejska-Polska-Ukraina. Społeczno-kulturalny, polityczny i gospodarczy wymiar współpracy"}

W dniach od 19-20 maja 2011 r. odbyła się w Gnieźnie Międzynarodowa Konferencja Naukowa Unia Europejska-Polska-Ukraina. Społeczno-kulturalny, polityczny i gospodarczy wymiar współpracy. Została ona zorganizowana przez Zakład Kultury Europy Wschodniej i Południowo-Wschodniej, Instytutu Kultury Europejskiej UAM. Patronat honorowy nad tym wydarzeniem objęli J.M. rektor UAM, prof. zw. dr hab. Bronisław Marciniak, J.E. ambasador Republiki Ukrainy w Polsce, prof. dr hab. Markijan Malskyj, marszałek Województwa Wielkopolskiego Marek Woźniak. W skład Komitetu Honorowego Konferencji weszli J.E. konsul honorowy Ukrainy w Poznaniu, Łukasz Horowski, starosta Powiatu Gnieźnieńskiego Dariusz Pilak, prezydent Gniezna Jacek Kowalski. Kierownictwo Komitetu Naukowego objęli panowie: prof. zw. dr hab. Leszek Mrozewicz i prof. dr hab. Orest Krasivskyy.

Konferencja została zorganizowana przy dużym wsparciu finansowym ze strony Urzędu Marszałkowskiego Województwa Wielkopolskiego i współdziałaniu z jego Biurem Współpracy Międzynarodowej, funkcjonującym pod kierownictwem Anny Markiewicz-Zielińskiej, dotacjom udzielonym ze strony starosty Powiatu Gnieźnieńskiego Dariusza Pilaka i J.M. rektora UAM, prof. zw. dr hab. Bronisława Marciniaka.

Uroczystego otwarcia konferencji w dniu 19 maja 2011 r. dokonał prof. zw. dr hab. Leszek Mrozewicz, dyrektor naukowy IKE UAM, następnie zabrali głos zaproszeni goście, J.E. ambasador Republiki Ukrainy w Polsce, prof. dr hab. Markijan Malskyj, marszałek Województwa Wielkopolskiego Marek Woźniak, prezydent Gniezna Jacek Kowalski, starosta Powiatu Gnieźnieńskiego Dariusz Pilak. Istotnym punktem tego dnia, była obok obrad plenarnych, promocja książki zatytułowanej Stosunki ukraińsko-polskie w latach 1917-1923, której autorem jest prof. dr hab. Orest Krasivskyy, kierownik Zakładu Kultury Europy Wschodniej i Południowo-Wschodniej IKE UAM. Obrady plenarne tego dnia podzielono na trzy części, a swoje referaty wygłosili m.in.: prof. dr hab. Markijan Malskyj Europejskie aspiracje Ukrainy podczas Prezydencji Polski w Unii Europejskiej, prof. dr hab. Henryk Stroński Polacy na Ukrainie wobec spraw polskiego dziedzictwa kulturalnego na Wschodzie, dr Jan Malicki Polsko-ukraińska wspótpraca naukowa. Programy stypendialne Rzqdu Polskiego dla młodych obywateli Ukrainy, 
doc. dr Petro Kohut Політико-владна персоніфікація у європейській перспективі України: теоретико-методологічний аспект, prof. dr Mykoła Kuczerepa Stosunki ukraińsko polskie w badaniach naukowców Wolyńskiego Narodowego Uniwersytetu im. Łesi Ukrainki w Łucku, Aleksander Wasilewski Ukraina i Morze Czarne a polityka energetyczna Unii Europejskiej.

W dniu 20 maja uczestnicy konferencji obradowali w sekcjach, podzielonych ze względu na tematy wystąpień (Unia Europejska-Polska-Ukraina. Wyzwania polityczne, wojskowe i historyczne, Unia Europejska-Polska-Ukraina. Wyzwania dla nauki i pedagogiki, Unia Europejska-Polska-Ukraina. Przeszłość i przyszłość). Zamknięcia i podsumowania konferencji dokonali wspólnie prof. dr hab. Orest Krasivskyy, dr Katarzyna Jędraszczyczyk, dr Witold Sobczak.

Podczas trwania konferencji poruszono wiele ważnych kwestii będących przedmiotem współczesnej polityki, spraw dotyczących społeczeństw i państw Unii Europejskiej oraz Europy Wschodniej, w obszarze wpływu byłego ZSRR. Poszukiwanie wspólnej drogi do realizacji najważniejszego celu, jakim jest integracja europejska, która musi dokonywać się z poszanowaniem praw człowieka przy uwzględnieniu różnic i indywidualnych celów politycznych i społecznych zarówno Polski, Ukrainy jak państw członkowskich Unii Europejskiej, było najważniejszym przedmiotem rozważań podejmowanych podczas obrad w Gnieźnie.

Wymiana myśli i poglądów podczas trwania konferencji, stała się impulsem do poszukiwania rozwiązań, które mają ułatwić wspólny dialog na linii Unia Europejska-Polska-Ukraina w celu dalszej integracji europejskiej, demokratyzacji i współpracy na szczeblu państwowym (centralnym) i w wymiarze lokalnym. Spotkanie przedstawicieli ludzi nauki, świata polityki, religii, ekspertów w dziedzinie gospodarki i ekonomii w Gnieźnie, w miejscu które w dziejach Polski i Europy odegrało istotną rolą $\mathrm{w}$ procesie integracji, $\mathrm{z}$ całą pewnością zaowocuje badaniami w przedmiocie relacji kulturowych, politycznych i gospodarczych między Unią Europejską, Polską i Ukrainą. Tematyka konferencji i szerokie podejście do problemu, umożliwiło podjęcie wspólnych poszukiwań w celu wypracowania mechanizmów współpracy, które mogłyby zostać zastosowane w praktyce.

Konferencja stanowiła istotny wkład w rozwój badań prowadzonych w Instytucie Kultury Europejskiej UAM, akcentując jednocześnie obecność Uniwersytetu w Gnieźnie i całym regionie. Wydarzenie to umożliwiło zacieśnienie współpracy międzynarodowej w ramach działalności samorządowej oraz współpracy na polu nauki między ośrodkami uniwersyteckimi w Polsce i na Ukrainie, w szczególności zaś Instytutu Kultury Europejskiej UAM, potwierdzając znaczenie Gniezna jako ośrodka akademickiego.

Przedsięwzięcie, jakim była konferencja zorganizowana w Gnieźnie przez Zakład Kultury Europy Wschodniej i Południowo-Wschodniej, niewątpliwe otwiera nowy rozdział $\mathrm{w}$ badaniach prowadzonych przez pracowników tego Zakładu. Nowe kontakty umożliwiają szerszy i lepszy dostęp do materiałów, które mogą być wykorzystane w badaniach, a także znacząco wpływają na logistykę 
przygotowywanych wyjazdów studyjnych. Należy mieć nadzieję, że dzięki konferencji nawiązana zostanie stała współpraca między Instytutem Kultury Europejskiej UAM w Gnieźnie a wiodącymi ośrodkami badawczymi na Ukrainie. Zaowocuje to wymianą naukowa, stażami, studyjnymi wizytami, a także konferencjami, wspólnymi projektami badawczymi i wymianą młodzieży.

Należy mieć nadzieję, że konferencja zorganizowana w Gnieźnie przez Zakład Kultury Europy Wschodniej i Południowo-Wschodniej IKE UAM, w dniach 19-20 maja 2011 r. będzie pierwszą z całego cyklu.

Witold SOBCZAK

Uniwersytet im. Adama Mickiewicza, Poznań Polska Akademia Nauk Instytut Nauk Prawnych 